\title{
Public-Private Partnerships in Forestry Management in Sri Lanka: Emergence, Influence and Legitimacy
}

\author{
Mangala De Zoysa (Corresponding author) \\ Department of Agricultural Economics, Faculty of Agriculture \\ University of Ruhuna, Mapalana, Kamburupitiya, Sri Lanka \\ Tel: 94-770-605-1540Ｅ-mail: mangalaxyz@yahoo.com
}

Received: March 27, 2020 Accepted: April 19, 2020 Published: April 26, 2020

doi:10.5296/emsd.v9i2.16752ＵRL: https://doi.org/10.5296/emsd.v9i2.16752

\begin{abstract}
Public-Private Partnerships (PPPs) are considered as "win-win" solutions to both government and market failures in sustainable forest management. PPPs in Sri Lanka are filling a regulatory gap resulting from withdrawal of government from the management of forest resources. The national forest policy has emphasized afforestation, conservation and protection as the main components of emerged government-community, donor-recipient and public-private partnerships with local people, rural communities and other stakeholders. Timber and fuel-wood plantations, and agro-forestry woodlots have been established through partnerships. Eco-tourism has been given special emphasis through partnerships between the government agencies, private sector and communities. Private sector involves in forestry as a business through sustainable agro-forestry, imparting financial gain. The government has identified risk mitigation as an integral part of the government-community partnership planning process. Investments of private sector in forest management are committed to enhance inflow of foreign exchange earnings through the export of value added forest products. The Forest Ordinance has empowered Forest Department for the management, protection and development of forest resources. PPPs are far less frequent in rule-setting and implementation of timber and fuel-wood plantations and agro-forestry woodlots. Work undertaken by community based organizations in PPPs occurs on a minor scale. Private-sector involvement in forest resources management has raised serious concerns by public perception about conflict of interest. The Government needs serious efforts and amendment of forest policies to promote public-private partnerships for the sustainable development of forest resources.
\end{abstract}

Keywords: Afforestation, Forest conservation, Forest protection, Community participation, Stakeholders participation 


\section{Background}

Public private partnerships (PPPs) are agreements between government and the private sector for providing solution to a wide variety of problems of governance reflecting mutual responsibilities in furtherance of shared interests (OECD, 1996). PPPs increase the effectiveness of their problem-solving capacity and democratic accountability of governance (Linder \& Rosenau, 2000). All members of successful partnerships are working toward the same end and dedicated to achieve common goals. Private actors in public-private partnerships are involved in policy-making including agenda-setting, negotiation, resource provision implementation, monitoring, and enforcement (Marx, 2019). The proliferation of publicprivate partnerships is rapidly reconfiguring the international forestry landscape. Both the private and the public sectors that play vital roles in modifying the forest management for public, private and community purposes have been identified as the major influencers. Publicprivate partnership approaches with the participation of all stakeholders well serve the major challenges of public forest management. PPPs improve the efficiency and effectiveness of sustainable forest management and provide "win-win" solutions to both government and market failures (Schäferhoff et al., 2009). PPPs are widespread in the areas of sustainable forestry management for the purpose of providing public infrastructure, community facilities and related services.

Forests cover 6.56 million hectares approximately $29.5 \%$ of the total land area in Sri Lanka. Forest plantations comprising of Teak, Mahogany, Eucalypts, Pine and other local species cover about 90000 hectares accounting nearly $1 \%$ of the total land area of the country. The government of Sri Lanka owns around $98 \%$ of the forest resources. The Forest Ordinance empower the Forest Department (FD) while the Fauna and Flora Protection Ordinance empower the Department of Wildlife Conservation (DWLC) under the Ministry of Environment (MENR) as public sector entities that legally own and manage government forest resources of the country (Ministry of Agriculture, Lands and Forestry, 1995a). The weak governance over forest resources neglected the forest conservation and rural development which increased tension among local communities over access and use of forest resources (Bergman and Murray-Rust, 2004). Timber harvesting of government's own forests is done by the State Timber Corporation (STC). Due to the prevailing financial incentives, illegal extraction of valuable timber from natural forests is however widespread.

Afforestation, conservation and protection activities in Sri Lanka are focused on consultation between government and local community base on the nature of the partnerships. Community-based management, community property rights and common property rights are very important for the sustainable management of natural resources particularly in developing countries (McKean, 2003). The community manages, use and control the forest and tree resources respecting the social, economic and cultural relationships between people and forests (FAO, 1997). The development of PPPs involved concentration of policy between public and private actors. The National Forestry Policy in Sri Lanka clearly lays out the major reorientations of the forestry sector that are required to successfully address the issues of deforestation, forest degradation and the direct and indirect effects of forest health on the livelihoods of the local communities and the natural environment. 
Institutional infrastructure of the forestry administration has decentralized up to a certain degree during the last few decades and pronounced community participation in forestry operations, mainly afforestation, conservation and protection (Wickramasinghe, 2013). The Forest Department in Sri Lanka is presently looking for avenues of effective PPP approaches of forest management, moving away from a command and control approach with limited community participation. PPPs continue to increase in popularity in the forestry sector in Sri Lanka as promising strategies, filling a regulatory gap created with gradual withdrawal of government from the forest management. The recent economic policy framework of Sri Lanka (Vision 2025) highlights the commitment of the government to encourage PPPs to strengthen the country's growth framework (Ministry of Finance, Government of Sri Lanka, 2018). This study attempts to analyze the present state of PPPs in terms of emergence, influence and legitimacy with a view of possible institutional development for the future sustainability of the forestry sector in Sri Lanka.

There is a growing body of knowledge but very limited research have been done about the PPP in wide range of forest management activities in Sri Lanka. The study uses emergence, influence and legitimacy approach to understand PPP in different forest management activities in Sri Lanka by assessing the involvement of government agencies and their interactions with private sector key stakeholders. The emergence of public-private partnerships combines public and private policy instruments and all components of the policy-process in more collaborative form of governance (Lambin \& Thorlakson, 2018). The actors in PPPs develop relations and influence the projects to make specific attention towards sustainability concerns in the implementation (Marx, 2019). Legitimacy is not only about direct decision-making influence, but also assure the decisions have been made in a fair and unbiased manner through transparency and representation of relevant social and interest groups (Tyler \& Lind, 1992). Participation of actors and their responsibility is more important in judging the legitimacy than democratic legitimacy of a system (Cashore, 2003). This study is based on a more flexible approach not sticking to strict formal methodology but reviewing literature and documents complemented with observations. It reviews information and program reports written on collaborative forest management found on the websites of the government and other stakeholders. Conducting personal discussions with stakeholders who are involving in different forestry projects was aimed to share from their expertise and experiences in PPPs of very complex forest management systems.

\section{Emergence of PPPs in the Forestry Sector}

\subsection{Policy Intervention}

\subsubsection{Forest Policy in 1980}

The rapid economic growth in 1980s and population increase significantly increased the demand for industrial wood products and compelled the government to adopt more sustainable forest management to maintain a reasonable level of self-sufficiency in timber both round and sawn (Nanayakkara, 2001). The national forest policy was then formulated and adopted in 1980 that emphasized the great need for sustainable management of forest resources with the involvement of local communities, by changing the forest ordinance that 
enacted in 1907 (Ministry of Agriculture, Lands and Forestry, 1995a). The policy directed the forestry administration to manage the forest resources to supply timber and fuel-wood with the involvement of local communities, through development of private woodlots and forest farms under social forestry programs (Senevitarne, 1982). The communities had to be empowered with knowledge of the ecosystem, best practices, and technologies, and facilitated with market linkages, access to credit and ability to partner with the government, private sector, NGOs and other entities. The community forestry systems were expected to conserve forest biodiversity, maintain and develop forest ecosystem services, produce forest goods and services, and create revenue and livelihoods on a sustainable basis. The community had being enjoying the usufruct of the forest lands belonging to the government until the introduction of modern community forestry concepts. Afforestation, conservation and protection were the main forestry operations and pronounced components of the emerged government-community partnership to varying degrees. The National Forest Policy of 1980 provided the legal rights to the Forest Department and the Department of Wildlife Conservation regarding ecotourism activities in natural forests in Sri Lanka (Pathmasiri \& Bandara, 2019).

\subsubsection{National Forestry Policy of 1995}

The National Forestry Policy of 1995 accepted joint forest management and leasehold forestry as promising strategies. The policy attempted to promote the constituent partnerships with local people, rural communities and other stakeholders in order to promote PPPs for the sustainable management of forest resources (Ministry of Agriculture, Lands and Forestry, 1995b). By the time, the country had experiences of the exploitation of the forest resources particularly declining the close canopy forest cover to $22.4 \%$ of the total land at the rate of $1.14 \%$ (Ministry of Environment and Natural Resources, 2002). The average rate of deforestation was around 42000 ha per year declining per capita forest land from 0.32 ha in 1956 to 0.09 ha in 1992. Rehabilitation of degraded forest land was proposed as forest for conservation and multiple-use production for the benefit of local communities. The importance of forest governance in government legislation became accepted to promote PPPs in forest management mainly by legal frameworks that secured private and community-based land tenure. Participatory approach was considered as an integral component in forest practices in terms of donor-recipient and public-private, in donor-assisted projects. Under the National Forest Policy in 1995, establishment of timber and fuel-wood plantations, agro-forestry woodlots, delineation and protection of forest boundaries, and mangrove management have been emphasized in the partnership with the government, community and other stakeholders (FAO \& FD, 2009). The policy emphasized commercial forest plantation development by private sector management to produce sufficient industrial and other woods to meet increasing demand. Forestry Master Plan in 1995 emphasized bringing in the private sector for forest plantations on lease agreements that the Forest Department would provide technical advice required for the establishment and management of plantations (De Zoysa, et al., 2002).

\subsubsection{National Ecotourism Policy in 2003}

The National Ecotourism Policy was drafted by the Ministry of Tourism in 2003 to facilitate 
the development of community owned and managed ecotourism enterprises in Sri Lanka with one of the main objectives of the conservation of natural ecosystems (Pathmasiri \& Bandara, 2019). Government - community partnerships in forest-based ecotourism promises to deliver economic development of the rural communities while conserving precious environments and reducing government funding in forest conservation.

\subsection{Implementation of Forestry Development Projects and Programs}

The Forest Department did not change its structure to form a specific social forestry section in 1982. The large donor-funded forestry projects were operated as completely separate programs (Carter et al., 1994). Subsequently, FD directly involved in reforestation activities and adopted forestry extension, environmental forestry, community forestry, and urban forestry in the mid-1980s. The Government formulated a forestry sector development strategy and Forestry Master Plan (FMP) in 1986 to address the rapid deforestation and introduce sustainable forestry management system (Nanayakkara, 2001). The main objectives of the FMP were to: 1. Create, maintain, and conserve forests in order to preserve the environment; 2. Protect and augment the supply of small woodlots for fuelwood; 3 . Maintain a sustainable yield of timber and other forest products; and 4. Involve local community in developing private woodlots and tree farms (ADB, 2003).

\subsubsection{The Farmer's Wood Lot (FWL)}

The Community Forestry Project (CFP) in 1982 developed the Farmer's Wood Lot (FWL) as a model and the Participatory Forest Project (PFP) launched the model in 1992 with the direct partnership between FD and communities. These programs sought PPPs to motivate farmers to plant timber trees and their agricultural crops together in degraded shifting cultivation lands. Farmers' Woodlot program under a special reforestation scheme, distributed 1500 ha lands in the Dry Zone among the farmers by the Forest Department on 30-year leases to plant teak and mahogany as the most common tree species.

\subsubsection{SGP PTF and SLANRMP}

The Small Grants Program for operations to promote Tropical Forests (SGP PTF) was implemented by the UNDP in Sri Lanka from 2004 through 2007 as an innovative, community-based forest-related project with the aim of building grassroots capacities for localised management through partnerships and networks. The Sri Lanka Australia Natural Resource Management Project (SLANRMP) mobilised target communities and provided them with necessary support for institutional capacity building to form groups and institute for formally registered community-based organisations (CBOs).

\subsubsection{Home-garden Subcomponent of the Participatory Forestry Project (PFP)}

The poor rural communities' participation in home-garden subcomponent of the Participatory Forestry Project (PFP) during 1993-2000 improved their livelihoods and the health status by growing and selling timber, crops and fruits at local markets. The approximately 9851250 home-gardens covering $9701 \mathrm{sq} \mathrm{km}$, around $22 \%$ of the total land area supply more than $70 \%$ of the timber and $80 \%$ of the fuel wood as a well-developed agroforestry system in Sri Lanka 
(UN-REDD Program, 2012). Traditional home-gardens in Sri Lanka grow multipurpose trees, shrubs, annual and perennial crops, and rear livestock within the compounds of individual houses and managed by the family labor.

\subsubsection{Forest-based Ecotourism}

Ecotourism was emphasized in Tourism Development Strategy of Sri Lanka in 2011 - 2016 as an initiative to make the country a carbon neutral destination. Ecotourism has become one of the progressive small-scale tourism activities and also a tool for conservation, and an integrated part in the forest management system of the country. Partnerships between private sector, the government resource managing agencies (FD and DWLC), and communities promote forest-based ecotourism while conserving ecosystem and benefiting the communities. Forest-based ecotourism, a non-land based model of sustainable forest management involving different form of PPPs was emerged in Sri Lanka by increasing number of visitations due to the inherited diverse forests, wildlife resources and a rich cultural heritage. Wickramasinghe (2013) has identified three basic management models of forest-based ecotourism in Sri Lanka: a. Businesses initiated by FD, managed by communities and funded by external sources; $b$. Community promoted and supported by NGOs; and c. Businesses owned and managed by private entrepreneurs. According to the Sri Lanka Tourism Board (SLTB) (2003), the ecotourism stakeholders are categorized as: the business community (operators, investors, and developers), visitors (local and foreign tourists), host population (residents), and government agencies (who manage the destination).

\subsubsection{Private Sector for Forest Plantations}

Touchwood is a private sector company involved in forestry sector through sustainable agro-forestry as a business. Imparting financial gain of a sound investment Touchwood also wishes to create a cleaner and greener planet. Touchwood, the only forestry investment company that was listed on the Colombo Stock Exchange in 2006 has developed more than 500 ha of forest lands during the past eight years, since its inception.

\section{Influence of PPPs for Improvement of Forest Management}

\subsection{Influence of Community in Forest Management}

Some communal forest lands in Sri Lanka are in the hands of the indigenous communities with roots in ancient forest cultures. The Veddas ('people of the forests') in Sri Lanka are the oldest indigenous group descended from communities who lived during the Neolithic. In agreement with the government, they protect their forest, cultural identity, language, religion and traditions in the jungle village of Dambana (Mahiyangana District). The FD and DWLC had recognized that the determinants of sustainable forest management were very broad and the sector is so large that the government organization can tackle it alone. Emerging management problems required a range of responses beyond the capacity of the forestry administration and partnerships had to be built between the stakeholders. Both private and the public sectors in community forest management have become influencers, and play vital roles in modifying the forest management for public and community purposes. The reasons of many participants for pursuing partnership vary with the value of partnerships in forest 
management perspective. Influence of community participation in forest resource management and conservation activities in Sri Lanka is still poor with the limited financing mechanisms to improve local livelihoods and secure environmental integrity. The mechanism has to be developed to reap beneficial impacts of the payment for environmental services (PES) and environmental service markets (Kallesoe \& De Alwis, 2005).

\subsection{Utilization of Degraded Lands and Home-gardens for Agro-forestry Development}

Farmer woodlot development program has distributed some degraded government forest lands among communities promising the prospect of prosperity for peasant groups without claiming to customary inherited lands. Abandoned lands in tea estates have been distributed among labor communities by the government to establish agro-forestry with the aim of improving their livelihood, protect the eco-system and retain social stability from rural urban migration. SGPPTF has recognised PPPs for combining local and scientific knowledge to support resource management and livelihoods for the benefit of the environment and the commercial development of specific resources. The home-garden provides ecosystem services, household needs and part of the household livelihood strategy. The agroforestry practices of home-gardens contribute directly in food production, and indirectly improving soil conditions and ecological security. Hence, diversified production of agroforestry practices in home-gardens has become a form of avoidance of risks and supply of food under the current agricultural crises of the country. The significance of home-gardens with regards to $\mathrm{C}$ sequestration and other $\mathrm{CO}_{2}$ mitigating effects has been already recognized. Pasture development program on silvo-pastoral systems of home-gardens has become a very important strategy to improve feed resources and very popular approach to cope with feed as a major constraint to milk production (De Zoysa, 2018).

\subsection{Forest-based Rural and Tourism Industries}

There is increasing production of a range of non-timber forest products (NWFPs) including rattan, bamboo, traditional foodstuffs, spices, medicinal plants and herbs, fruits, seeds etc., as natural products in nature-based tourism in partnership with forest-based rural industries and tourism industries. Non-traditional export crops mainly originating from small holder agroforestry systems including spices, coffee, arecanuts, cashew nuts, vegetables and fruits, with the support of export industries are experiencing competitiveness in the world market (Thamiem et al., 2011). Several nongovernmental organizations (NGO) are involving in isolated forest management projects in Sri Lanka. The NGOs link the public with the private sector through resource transfers. They support public side to provide organizational, material and financial resources to enable the private and community partners carry out the public forestry programs. The existing political condition prevents large-scale involvement of private sector in the forestry sector. Protests by the relevant trade unions of the STC do not allow timber harvesting by 'open bidding' with private sector collaboration. Partnerships limit the motivation of partners of profit-oriented enterprises to allocate resources and reduced their involvement in many partnership projects over time (Bull, 2010). Forest-based ecotourism blessed with diverse forests, wildlife resources and rich cultural heritage is one of the fastest growing industries in Sri Lanka which conserve the environment and improve the 
well-being of local people (Steele et al., 1998). Establishment of timber and fuel-wood plantations, agro-forestry woodlots, mangrove management and ecotourism in partnership with community and other stakeholders are based on the participation of private interests in the strategic-level decision-making on public interest. Local people, rural communities and other stakeholders influence the behavior of their respective organizations to achieve partnership goals and/or influence public policy through network associations.

\subsection{Increasing Markets for 'Ecological Services'and Identified Risk Mitigation}

Increasing demands in markets for 'ecological services' particularly carbon need taking into consideration to explore the contested reform process. PPPs in forest management have recognized diverse activities which involve the generation of numerous non-extractive forest uses and eco-system services related to conservation and restoration. Linkages and interactions between public and private sectors in the context of formulating climate change policy yet to be achieved through more effective forest policy to promote the joint provision of goods and services (Ministry of Environment, 2007). An inter-sectoral coordination and cooperation is required for the implementation of climate-smart agroforestry activities at the landscape scale beyond the farm scale (Scherr, et al., 2012). International organizations incorporate private consultants rather than government officials and community representatives in rule-setting and rule-implementation, at complex negotiating systems in climate change. Community managing the forest eco-systems seeks public partnership in adaptation to climatic shifts and erratic climate events, and to protect important water resources and downstream ecosystems. It is expected that more stakeholder participation in protective spheres in forestry will maintain environmental safeguards, aesthetic and recreational significance (Forest Department, Government of Sri Lanka, 2009). The local community is one of the targeted beneficiary groups of ecotourism projects are protecting the ecotourism destinations from the adverse effects as the guardians. One of the main objectives of the National Ecotourism Policy in Sri Lanka drafted by the Ministry of Tourism in 2003 was the conservation of natural ecosystems (Pathmasiri \& Bandara, 2019). Forest-based ecotourism under community forestry project was identified as a tool for conservation where forest degradation had been a severe issue while benefiting communities (Wickramasinghe, 2013). Protection of quality natural resources through the competitiveness of ecotourism destinations is the driver of economic benefits (Boley \& Green, 2016). Touchwood, through profiting, protecting the environment and being socially responsible, attempts to be a triple bottom line company. Touchwood offers investment options in forest plantations and agroforestry systems and empowers individual investors for ecological and environmental gain more than the financial gain. Through investment partnerships, the company brings investment resources, business management expertise, and market links for the forestry businesses managed by the individuals. Agroforestry systems introduced by Touchwood serve to provide quality habitats important for biodiversity conservation.

Bringing the illegal encroachment and logging of government forests to a halt was one of the main objectives of establishing Farmer Wood Lots (FWL) (Kallesoe \& Alvis, 2005). The forest Department had recorded average 670 forest offences involved with $1,130 \mathrm{~m}^{3}$ worth of Rs. 5.2 million (US \$ 500 000) illegal cuttings per year from 1991 to 1995 (Bandaratillake, 
2001). These programs have identified risk mitigation as an integral part of the governmentcommunity partnership planning process reaching consensus, and negotiation of a compromise. Public-private partnership has become the popular set up and main campaign to combat illegal logging and forest crimes in conserved forests of the country. PPPs concern the mutual resource dependency of public and private stakeholders and increase the capacity of problem-solving in governance arrangements (Schäferhoff, 2009).

\subsection{Enhance Foreign Exchange Earnings, and Research and Development}

Agro-forestry, reforestation, afforestation and plantations are promoted under CDM (Clean Development Mechanism) projects in Sri Lanka to provide an opportunity for poor households to participate in forest management and gain financial rewards through carbon trade. Sri Lanka is still in its very initial stage to establish a formal market for carbon credits. The eco-tourism is a profitable niche market which eco-tourists are willing to pay more than other tourists. About 0.8 million foreign tourists have visited natural forest areas as ecotourism destinations in 2016 (Pathmasiri \& Bandara, 2019). Foreign eco-tourists stay average seven days in the eco-lodges paying average US \$ 65 per day (Bandara, 2009). Touchwood attempts to enhance foreign exchange earnings into the domestic macro-economy through the investments in forest management. Touchwood Investments would enhance its contribution exporting value added forest products of Vanilla, Sandalwood, Mahogany and Teak.

Research programs conducted by the forest department and public-funded universities improve the policy implementations for the sustainability of forest management (Forest Department, Government of Sri Lanka, 2009). Research and development is one of the most effective approaches to PPPs accelerating the transfer of public knowledge and technology into the private sector. Even though the scope for development of large-scale forest industries in the future is lesser, development of industries based on non-forest tree resources in the country are anticipating knowledge and technology. Non-forest lands including home gardens, rubber, coconut and tea plantations which are managed by individuals and private firms supply a wide range of forest resources in addition to the natural forests and the forest plantations. PPPs maximize the provision of goods and services jointly from public and private forests according to the climate change research to achieve more effective forest policy (Ministry of Environment, 2011).

\section{Legitimacy in PPPs for Sustainable Forestry Development}

\subsection{Participation of PPPs}

\subsubsection{Forest Officers}

The Forest Ordinance of Sri Lanka has empowered the forest officers to enact its provisions with the objective of protecting the national forest resources, prevention of land degradation and conservation of water. The Forest Officers are responsible to manage, protect and develop the forest resources in the country. According to the forest policy in 1980, acting in the public interest, The FD is supposed to create favorable conditions for private sector and also to produce products and services from the forest resources. Concerning rule setting, 
forestry authorities are rather reluctant to delegate authority to community actors or to include them into their negotiating systems.

\subsubsection{Community Based Forest Groups and Agroforestry Farmers}

Community based forest groups and community based forest management strategies are attempting to make the foundation of grassroots level democracy. Community as a homogeneous, functional, and moral group of persons living and working together are able to develop the capacity for consensus decision-making and collective action in forest management under common property regime. Large numbers of communities in forest areas are engaged in complex processes to defend their rights of different management systems for generations under gaining policy and political environments. Many community forestry programs introduced by the government and the international donors designed to favor communities have been only partially successful due to the failure to provide secure tenure rights or access rights to the resource. The Forestry Master Plan (FMP) in 1986 prepared with the assistance of the World Bank was one of the first in the region but was criticized for failing to involve all the key players in the planning process (EU - UNDP, 2004).

Although Sri Lanka has recognized the role of women in the conservation and utilization of natural resources under Rio and Agenda 21, it has not been imposed at the policy level in community forest management. More than $30 \%$ of the workforce employed in forestry sector is women. They are mainly involving in tree-planting work, nursery work and maintenance work through the long tradition of gender equality in the country (Wickramasinghe, 1997). Despite the intrinsic attributes of unique land use activity, agroforestry has not attracted much attention from the community in PPPs due to inconsistencies in under-storey crop productivity and insufficient policy support (Kumar, 2006). Legitimacy needs to be appropriate within socially constructed system of norms, values, beliefs, and definitions (Suchman, 1995).

The pasture development program implemented in home-gardens in Southern Sri Lanka has created some considerable changes in ecosystem as well as significant economic trade-offs and social breakthroughs. Developing and popularizing fodder resources among small cattle farmers requires strengthening PPPs particularly the institutional support for the research and extension. The program has to promote community governance and attract externalities including land use planning including village forest, cropping systems selection, technology development, and introduce high yielding shade tolerance food crops together with policy support required for the sustainability of pasture development programs. Establishment of farmer organizations is required to empower the farmers and encourage them for collective efforts to improve the standards of their dairy farming (De Zoysa, 2018).

\subsubsection{Community Based Organizations (CBO)}

A large number of community based organizations have created the institutional setup in Sri Lanka for implementing payment for environmental services (PES), and pooling the providers of service without clearly identifying ecosystems services, values and the beneficiaries (Kallesoe \& De Alwis, 2005). Community based organizations (CBO), in the 
forestry sector undertake minor scale works with foreign-funded projects. The scope of their works such as raising seedlings in temporary nurseries, establishment of community woodlots, forest boundary maintenance, are limited to the project duration (Forest Department, Government of Sri Lanka, 2009). Reforestation and soil conservation efforts of watershed management undertaken through local CBOs have improved the relationships between resource utilization and environmental impacts. CBOs have been formed for protecting the forest and introduced confidence-building measures in some buffer zone villages (UNDP, 1999). They are permitted to involve in activities such as joint forest management, participatory forest management and sustainable use of non-wood forest products. The primary objective of the community based organization CBO (Dumbara Surakinno) in the Ecotourism Project in Illukkumbura is to protect the Knuckles rainforest (Wickramasinghe, 2013).

\subsubsection{Civil Society}

Partnership between all three sectors public, private and civic working together is the best way to overcome many socio-economic and legal problems in management of government forest resources. PPPs emphasize on strengthening civil society in the development of forestry policies. Voluntary partnership agreements of civil society with public sector combat forest crimes, imposing forest laws in forested areas of the country. Insufficient government personnel and the distance from resources often become difficulties in law enforcement to protect forest resources (ITTO, 2006). Involvement of local people in resource monitoring in the wildlife corridors in hotspots is a long tradition in Sri Lanka (Conservation International, 2007). Youth committees were formed by the SCPPTF shaping the values of future leaders in rural societies to protect and sustainably manage the forest resources in buffer zones of the natural forests (Sandiford 2007).

\subsection{Rule-setting and Implementation}

Involvement of stakeholders in rule-setting lead to better governance building consensus and compromise (Scharpf, 1997). Since the adoption of markets-based economy approach in 1977, the government of Sri Lanka use market based instruments to regulate and control environmental utilization and pollution through numerous environmental laws, decrees and acts. However the legal framework has not yet been developed on rewarding positive environmental externalities mainly for environmental services (Kallesoe \& Alvis, 2005). A universal formula has not yet been developed in order to promote the accountability and legitimacy across the institution for sustainable development (Bernstein, 2005). The national forest policy of Sri Lanka was amended in 1980 with social forestry as a strategy to develop private woodlots and forestry farms with the involvement of local community under social forestry programs. Community forestry enhances the capacity of communities to participate meaningfully and represent their interests in agenda-setting and decision-making in sustainable forest management (CIFOR, 2007). However, the amendment was not supported by revising the forest legislation of the country (Senevitarne, 1982). PPPs are not frequently involving in the rule-setting and management of timber and fuel-wood plantations, agro-forestry woodlots, mangrove management and ecotourism which are strategically important for sustainable forest management. However, the government agencies delegate 
responsibilities to conduct ecotourism activities to the local communities after initiating ecotourism destinations where socio-culture is considered as ecotourism attractions. The government agencies initiated Dambana ecotourism project and created markets for the products such as handicraft, honey, and indigenous medicine produced by the aboriginal people (Vadda) (Bandara, 2009). Delegation of power and resources to stakeholders is an important strategy for ensuring good governance and integrate them for sustainable ecotourism (Pasape et al., 2015). The Forestry Master Plan (FMP) - 1986 in Sri Lanka was one of the first in the region but was criticized for failing to involve all the key players in the planning process (EU - UNDP, 2004). The decisions, such as the selection of the project's location, land distribution and planting design in the FWLs programs in the Badulla and Kandy districts, were done by project officials without considering the importance of partnership development.

\subsection{Management, Ownership and Property Rights}

Nature of forest control and the form of ownership provide is an essential link between forest resources and their use to meet increasing demand to produce sufficient forest products (De Zoysa, et al., 2002). Providing property rights to the communities creates incentives for reforestation and sustainable forest management. Providing local communities with tenure rights and land ownership through the decentralization process and delegation of authority to provincial and local level authorities, the government expected to have a positive impact on transaction costs associated with payments and markets for environmental services (Kallesoe \& Alvis, 2005). In 1995 the government with the assistance of ADB formulated and adopted National Forest Policy and institutional reform. The legislation facilitated the: 1. Permits for transport of timber grown by the private sector; 2. Private sector participation in harvesting, establishment, and management of state-owned plantations, and 3. Granting them 25 year leases or management rights to forestlands (ADB, 2007). The National Forest Policy described the main guidelines to include community participation as: 1 . Form of partnerships with local communities through appropriate tenurial arrangements to manage and protect the forest plantations and natural forests; 2. Entrusted local communities, forest industries and other private bodies to establish and manage industrial forest plantations on the government lands; 3. Rehabilitation of degraded forest land as forest for conservation and multiple-use production for the benefit of local communities. The Forestry Sector Master Plan of Sri Lanka in 1995 identified home gardens as the main source of timber and fuel-wood considering that the main causes of deforestation and forest degradation is poverty associated with landlessness and poor land tenure system (ADB, 2001). The concept of community forestry was promoted by the Forestry Sector Master Plans for distributing forest resource benefits among local communities thus alleviate rural poverty while conserving the forest resources (De Zoysa \& Inoue 2007). The effectiveness of governance depends on the flow of benefits which the community would reap from the forest resource system (Agrawal 2007). Unsecured property rights generally limit the community participation in forest resource management and conservation activities in Sri Lanka. In some cases, local communities are granted with tenure and land use rights providing incentives to engage them particularly in watershed conservation efforts. 


\section{\لMacrothink}

The approach of management and ownership of the business, forest-based ecotourism in Sri Lanka is categorized under three basic management models as: a. Ecotourism businesses initiated by the government organization, financially supported by external sources and managed by communities; b. Community-based ecotourism projects initiated and financially supported by NGOs; and c. Ecotourism businesses managed and owned by the private entrepreneurs (Wickramasinghe, 2013). Non-profit organizations emerged as grassroots and peasant movements in close collaborations with NGOs to access funding and public representation. Development of strong partnership with private sector with experience in managing tourism is a pre-requisite for the government organization (FD and DWLC) to implement forest-based ecotourism. The government organizations and private sector have not adequately recognized the community as a stakeholder in developing forest-based ecotourism in community managed forested areas. Lack of recognition of communities as a partner in ecotourism businesses run by private sector has often led to community resistances. Lack of knowledge and experience in undertaking eco-tourism as a business and conflicts arising among the community in benefit sharing are hereby identified as main constraints.

\subsection{Regulatory Issues}

The Forest Ordinance amended in 1998 has focused on government regulations aimed at controlling environmentally harmful activities (Kallesoe \& Alvis, 2005). The IUCN global project on Forest Law Enforcement and Governance (FLEG) supported Sri Lanka in improving forest governance involving civil society and the private sector in forest management (EU 2007). The individual investors in agroforestry systems of Touchwood participate in the strategic-level decision-making also in the public interest for ecological and environmental issues. The national campaign to plant Sandalwood trees, a native tree, in all places of religious significance throughout the country was a success with the continued guidance and assistance of the FD. Permit systems, designation of species and areas; restrictions on commercial harvests; un-recognized local forest use, access, and ownership rights creating regulatory barriers and preventing the promotion of forest-based enterprises need to be addressed through the strong PPPs. The Forest Department in 1960 issued permits for the farmers to cultivate cardamom under forests within the Knuckles Range. Eventually, Knuckles Range was declared a Man and Biosphere Reserve in 1988 in order to conserve the forest from degradation, and slash and burn practices of commercial cardamom cultivators. In response to the severe impact on local livelihoods, the "Innovations and Application of Participatory Economic Planning for Conservation of Biodiversity and Water Resources in the Knuckles Range of Forests Project" in 2002 implemented "Sustainable agricultural practices in homestead gardening" and "eco-tourism" as an income generating conservation supporting initiative. (Kallesoe \& Alvis, 2005). A tripartite joint forest management model bridge the governments, private sector and communities for greater accountability in the Knuckles forest range (IUCN, 2006).

\subsection{Public Perception}

Public perception of the shift in paradigm toward public-private partnering raise questions about whether the FD in Sri Lanka is really prepared for this partnership. Due to the weak 
partnerships people are made to feel that community forests are no man's lands and nobody is responsible for managing these forest resources in a sustainable manner. The local community requires legality of community forests and their connections to forest management which are crucial for the protection and sharing their benefits. Involvement of private-sector has raised serious concerns about their conflict of interest in forest resource management. Community managed eco-tourism avoids the incursion of commercial interests seeking private profit, and facilitates community control for conservation and local well-being. Existing environment and tourism policies and present legal framework of the country are not strong enough to assure sustainability for forest-based ecotourism which are taking place in fragile natural environments and socio-cultural set-ups (Ratnayake, 2007).

\section{Conclusion and Policy Implications}

The emergence, influence and legitimacy of PPP arrangements vary enormously according to the types and purposes of forest management systems in Sri Lanka. The PPPs in forestry sector of the country have emerged mainly to deal with forestry problems related to conservation faced by public sector and reaping benefits for private sector particularly the community. They require a wide range of responses beyond the capacity of either the public or the private sectors working independently. The PPPs have influenced private and the public sectors in modifying the forest management to some extent according to the public, private and community interests. The legitimacy of forest governance in democratic participation and accountability is still required to promote popular support for PPPs and effective management of forest resources. The forest policies of the country are not directly committed in promoting PPPs in managing forest resources. The government requires strong management efforts and strategies to promote PPPs with appropriate national regulatory frameworks and governance system for the sustainable development of forest resources. Good governance that promotes the rule of law, transparency, accountability, and the meaningful PPPs in local decision-making processes is necessary for the development and implementation of national forest policies effectively.

\section{Acknowledgement}

This paper was presented at the Timber Legality Research Symposium hosted by The University of Copenhagen, Denmark on October 17-20, 2018 with the generous support from the FLARE network.

\section{References}

Agrawal, A. (2007). Forest Governance, and Sustainability: Common Property: Theory and its Contributions. Igitur, Utrecht Publishing \& Archiving Services for IASC. International Journal of the Commons, 1(1), 111-136. https://doi.org/10.18352/ijc.10

Asian Development Bank (ADB) (2001). Project completion report on the participatory forestry project (Loan 1183-SRI[SF]) in Sri Lanka. ADB, Philippine

Asian Development Bank (ADB) (2003). Project performance audit report On the participatory forestry project (Loan 1183-SRI[SF]) in Sri Lanka. ADB, Philippine. 
Asian Development Bank (ADB) (2007). The Forest Resource Management Sector Project (FRMSP). Ministry of Forestry and Environment, Sri Lanka.

Bandara, R. (2009). The Practice of Ecotourism in Sri Lanka: An Assessment of Operator Compliance towards International Ecotourism Guidelines. South Asia Economic Journal, 10(2), 471-492. https://doi.org/10.1177/139156140901000209

Bandaratillake, H. M. (2001). Impacts and effectiveness of logging bans in natural forests: Sri Lanka; Asia-Pacific Forestry Commission (Ed.), Forests Out of Bounds: Impacts and Effectiveness of Logging Bans in Natural Forests in Asia-Pacific. Asia-Pacific Forestry Commission, FAO, Bangkok.

Bergman, B., \& Murray-Rust, H. (2004). Managing conflict in watersheds of Sri Lanka. Colombo, Sri Lanka: USAID.

Bernstein, S. (2005). Legitimacy in global environmental governance. Journal of International Law and International Relations, 1, 139-66.

Bull, B. (2010). Public-private-partnerships: the United Nations experience. In G. Hodge, C. Greve \& A. Boardman (Eds.), International Handbook on Public-Private Partnerships. Cheltenham: Edward Elgar. https://doi.org/10.4337/9781849804691.00029

Carter, J., Connelly, S., \& Wilson, N. (1994). Participatory forestry in Sri Lanka: Why so limited? Change on the horizon. Network Paper 17b, Rural Development Forestry Network, ODI, London.

Cashore, B. (2002). Legitimacy and the privatization of environmental governance: How Non-State Market- Driven (NSMD) governance systems gain rule-making authority, Governance. An international journal of policy, administration and institutions, 15(4), 502-29. https://doi.org/10.1111/1468-0491.00199

Center for International Forestry Research (CIFOR), (2007). Forests and Governance program. Update October 02, 2007 of CIFOR. Bogor, Indonesia: CIFOR. [Online] Available: https://www.cifor.cgiar.org/Research/Governance/Research.htm

Conservation International. (2007). Ecosystem Profile: Western Ghats \& Sri Lanka. Critical Ecosystem Partnership Fund, Conservation International. [Online] Available: https://www.cepf.net/sites/default/files/western-ghats-ecosystem-profile-english.pdf

De Zoysa, M. (2018). Transformation of Traditional Silvo-Pastoral Home-Gardens: A Case Study in Southern Sri Lanka. Sustainable Agriculture Research, 7(1).

https://doi.org/10.5539/sar.v7n1p98

De Zoysa, M., \& Inoue, M. (2007). Community Forest Management in Sri Lanka: Concepts and Practices. Proceedings of International Symposium on Forest Stewardship and Community Empowerment: Local Commons in Global Context. Kyoto International Community House, Japan.

De Zoysa, M., Ariyadasa, K. P., \& De Silva, Y. Y. K. (2002). Private Forest Plantation 


\section{Mll Macrothink}

Environmental Management and Sustainable Development

ISSN 2164-7682

2020, Vol. 9, No. 2

Development in Sri Lanka: Issues and Challenges. Paper presented at the IUFRO Science/Policy Interface Task Force regional meeting held in Chennai, India at the M.S. Swaminathan Research Foundation. [Online] Available:

https://pdfs.semanticscholar.org/cbfb/852d981bf4eb5451aafcd64d3fb85422098d.pdf?_ga=2.7 $0798361.84482587 .1587203445-871681002.1557299232$

EU - UNDP (The European Commission, United Nations Development Program) (2004). Small Grants Program for Operations to Promote Tropical Forests (SGP PTF): Country Guideline Paper for Sri Lanka (2004-2007), Colombo, Sri Lanka.

European Commission (EU). (2007). Multi-annual Indicative Program for Asia 2007-2010. European Commission.

FAO (1997). People and Forests - Community Forestry at FAO, FAO, Rome.

FAO, FD. (2009). Sri Lanka Forestry Outlook Study, Working Paper No. APFSOS II/WP/2009/29. Asia Pacific Forestry Sector Study II. Working Paper Series. Food and Agriculture Organization of the United Nations Regional Office for Asia and the Pacific, Bangkok.

Forest Department, Government of Sri Lanka (2009). Asia-Pacific Forestry Sector Outlook Study II, Working Paper Series, Working Paper No. APFSOS II/WP/2009/29, Sri Lanka Forestry Outlook Study.

ITTO. (2006), Status of tropical forest management, ITTO Technical Series No 24. [Online] Available: https://scholar.google.com/scholar?q=ITTO,+2006,+Status+of+tropical+forest+ management,+ITTO+Technical+Series+No+24\&hl=en\&as_sdt=0\&as_vis=1\&oi=scholart

IUCN, (2006). Illegal Logging: A Commitment to Change Through Tripartite Action. Forest Law Enforcement and Governance (FLEG). Bangkok, Thailand: IUCN.

Kallesoe, M., \& De Alvis, D. (2005). Financial Incentives for Ecosystem Conservation: A review of the Development of Markets for Environmental Services in Sri Lanka. IUCN Water, Nature and Economics Technical Paper No. 4. IUCN-The World Conservation Union, Ecosystems and Livelihoods Group Asia, Colombo

Kumar, B. M., \& Nair, P. K. R. (2006). Agroforestry: the new old paradigm for Asian food security. Journal of Tropical Agriculture, 44(1-2), 1-14.

Lambin, E., \& Thorlakson, T. (2018). Sustainability Standards: Interactions between private actors, civil society and governments. The Annual Review of Environment and Resources. 43, 369-393. https://doi.org/10.1146/annurev-environ-102017-025931

Linder, S. H., \& Pauline, V. R. (2000). Mapping the Terrain of the Public-Private Policy Partner-ship. In Public-Private Policy Partnerships, Cambridge MA: MIT Press, 3-20.

Marx, A. (2019). Public-Private Partnerships for Sustainable Development: Exploring Their Design and Its Impact on Effectiveness. Sustainability, 11, 1087.

https://doi.org/10.3390/su11041087 
McKean, M. (2003). Common-Pool Resources in the Context of Japanese History. In Murota, T. (Ed.), Common-pool Resources in Japan and Worldwide from the Historical and Contemporary Perspectives. The Doshisha University Research Center for World Wide Business (RCWOB).

Ministry of Agriculture, Lands and Forestry (1995a). National Forest Policy and Executive Summary. Ministry of Agriculture, Lands and Forestry in November 1995.

Ministry of Agriculture, Lands and Forestry (1995b). Sri Lanka Forestry Sector Master Plan. Forestry Planning Unit, Ministry of Agriculture, Lands and Forestry.

Ministry of Environment (2007). Thematic Assessment Report on Climate Change, prepared for the National Capacity Needs Self-Assessment for Global Environmental Management. Colombo. Sri Lanka.

Ministry of Environment (2011). Information, Education and Communication Strategy for Climate Change Adaptation in Sri Lanka. pp. 10-15.

Ministry of Environment and Natural Resources Sri Lanka (2002). Report of Sri Lanka to the World Summit on Sustainable Development, Ministry of Environment and Natural Resources. Sri Lanka.

Ministry of Finance, Government of Sri Lanka (MOF, GOSL) (2018). Framework Development and Infrastructure Financing to support Public private Partnerships: Environmental Assessment \& Management Framework (EAMF). [Online] Available: http://documents.worldbank.org/curated/en/118181533221975321/Sri-Lanka-Framework-De velopment-and-Infrastructure-Financing-to-Support-Public-Private-Partnerships-Project-Envi ronmental-Assessment-and-Management-Framework-Executive-Summary

Nanayakkara, V. R. (2001). Regional study on forest policy and institutional reforms: Final report of the Sri Lanka case study. Asian Development Bank, Colombo, Sri Lanka.

OECD (1996). Shaping the 21st century: the contribution of development cooperation. Paris OECD.

Pasape, L., Wineaster Anderson, W., \& Lindi, G. (2015). Good governance strategies for sustainable ecotourism in Tanzania. Journal of Ecotourism, 14(2-3), 145-165.

https://doi.org/10.1080/14724049.2015.1065834

Pathmasiri, E. H. G. C., \& Bandara, T. W. M. T. W. (2019). Contradictory Conception and Implementation of Ecotourism in Sri Lanka. International Journal of Research Publication, $39(2)$.

Ratnayake, P. U. (2007). Challenges to Ecotourism Development in Sri Lanka: An Assessment. A thesis submitted in partial fulfillment of the requirements for the Degree of Master of Business Administration in Hospitality and Tourism Management, Prince of Songkla University, Thailand.

Sandiford, M. (2007). Lessons on sustaining communities and forests from the Small Grants 


\section{Macrothink}

Environmental Management and Sustainable Development

ISSN 2164-7682 2020, Vol. 9, No. 2

Program for Operations to Promote Tropical Forests (SGPPTF). Regional Community Forestry Training Center for Asia and the Pacific (RECOFTC), Bangkok 10903, Thailand.

Schäferhoff, M., Campe, S., \& Kaan, C. (2009). Transnational Public-Private Partnerships in International Relations: Making Sense of Concepts, Research Frameworks, and Results. International Studies Review, 11(3), 451-474.

https://doi.org/10.1111/j.1468-2486.2009.00869.x

Scharpf, F. W. (1997). Introduction: The Problem-Solving Capacity of Multi-Level Governance. Journal of European Public Policy, 4(4), 520-538.

https://doi.org/10.1080/135017697344046

Scherr, S. J., Shames, S., \& Friedman, R. (2012). From Climate-Smart Agriculture to Climate-Smart Landscapes. Agriculture \& Food Security, 1, 12.

https://doi.org/10.1186/2048-7010-1-12

Seneviratne, E. W. (1982). National Forestry Extension Programme. The Sri Lanka Forester, 15(3/4), 103-118.

Steele, P., Sivakumar, N., \& Herath, H. M. B. C., (1998). A Strategy for Nature Tourism Management in Sri Lanka. Institute of Policy Studies, Colombo.

Suchman, M. C. (1995). Managing Legitimacy: Strategic and Institutional Approaches. The Academy of Management Review, 20, 571-610.

https://doi.org/10.5465/amr.1995.9508080331

Thamiem, S., Weerahewa, J., Pushpakumara, D. K. N. G., and Singh, V. P. (2011). Trade Competitiveness of Agroforestry Crop Sector in Sri Lanka. Tropical Agricultural Research, 22(4), 338-347. https://doi.org/10.4038/tar.v22i4.3784

Tyler, T. R., \& Lind, E. A. (1992) A Relational Model of Authority in Groups. Advances in Experimental Social Psychology, 25, 115-191.

https://doi.org/10.1016/S0065-2601(08)60283-X

UNDP (1999). Contributing to the Conservation of the Unique Biodiversity in the Threatened Rain Forests of Southwest Sri Lanka. UNDP, Sri Lanka.

UN-REDD Programme (2012). Sri Lanka REDD+ Readiness. Preparation Proposal, UN-REDD Programme Eighth Policy Board Meeting. [Online] Available:

http://www.unredd.net/index.php?option=com_docman\&task=doc

Wickramasinghe, A. (1997). Women and Social Forestry in Sri Lanka. ENERGIA News Issue.

Wickramasinghe, K. (2013). Ecotourism as a Tool for Sustainable Forest Management in Sri Lanka. Journal of Environmental Professionals Sri Lanka, 1(2), 16-29.

https://doi.org/10.4038/jepsl.v1i2.5145 


\section{Macrothink \\ Environmental Management and Sustainable Development \\ ISSN 2164-7682}

\section{Copyright Disclaimer}

Copyright for this article is retained by the author(s), with first publication rights granted to the journal.

This is an open-access article distributed under the terms and conditions of the Creative Commons Attribution license (http://creativecommons.org/licenses/by/4.0/). 